\title{
Reflectance confocal microscopy features of facial angiofibromas
}

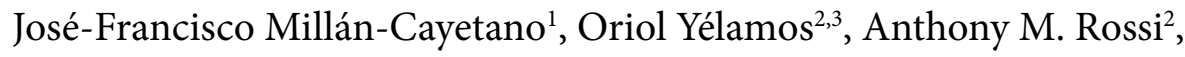 \\ Michael A. Marchetti², Manu Jain²
}

1 Dermatology Department, Hospital Costa del Sol, Marbella, Spain

2 Dermatology Service, Department of Medicine, Memorial Sloan Kettering Cancer Center, New York, USA

3 Dermatology Department, Hospital Clinic, Universitat de Barcelona, Barcelona, Spain

Key words: reflectance confocal microscopy, angiofibroma, fibrous papule, basal cell carcinoma

Citation: Millán-Cayetano J-F, Yélamos O, Rossi AM, Marchetti MA, Jain M. Reflectance confocal microscopy features of facial angiofibromas. Dermatol Pract Concept. 2017;7(1):10. DOI: https://doi.org/10.5826/dpc.0701a10

Received: November 16, 2016; Accepted: November 26, 2016; Published: January 31, 2017

Copyright: (92017 Millán-Cayetano et al. This is an open-access article distributed under the terms of the Creative Commons Attribution License, which permits unrestricted use, distribution, and reproduction in any medium, provided the original author and source are credited.

Funding: This research was funded in part through the NIH/NCI Cancer Center Support Grant P 30 CA008748 and the Beca Excelencia Fundación Piel Sana.

Competing interests: The authors have no conflicts of interest to disclose.

All authors have contributed significantly to this publication.

Corresponding author: Manu Jain, MD, Dermatology Service, Department of Medicine, Memorial Sloan-Kettering Cancer Center, 16 East 60th Street, New York, NY, USA. Tel. +1 646888 6109. Email: jainm@mskcc.org

ABSTRACT Facial angiofibromas are benign tumors presenting as firm, dome-shaped, flesh-colored to pink papules, typically on the nose and adjoining central face. Clinically and dermoscopically they can mimic melanocytic nevi or basal cell carcinomas (BCC). Reflectance confocal microscopy (RCM) is a noninvasive imaging tool that is useful in diagnosing melanocytic and non-melanocytic facial lesions. To date no studies have described the RCM features of facial angiofibromas. Herein, we present two cases of facial angiofibromas that were imaged with RCM and revealed tumor island-like structures that mimicked BCC, leading to skin biopsy.

\section{Cases}

Two women in their fifties presented with a bleeding lesion on their nose. At clinical examination, they presented as small pink papules; one was soft and one was firm on palpation. Polarized dermoscopy revealed a structureless whitish-pink background in both lesions, and an erosion was present in one case (Figure 1A). Due to the curvature of the face, a handheld reflectance confocal microscope (Vivascope 3000, Caliber I.D., Rochester, NY) was used. An adhesive paper ring was placed surrounding the lesion to guide RCM navigation [1].
The indication for RCM was to exclude BCC due to occasional bleeding. Other differential diagnoses included irritated angiofibroma, intradermal nevus, and adnexal neoplasm.

Reflectance confocal microscopy (RCM) showed a regular epidermal honeycombed pattern with BCC-like structures identified at the dermal-epidermal junction and papillary dermis (Figure 1C). These structures varied in size and shape and had increased cellular density compared to hair follicles. Many had clefting (dark signal-void region) around them. In the papillary dermis, abundant thick collagen bundles were identified mainly around hair follicles (Figure 1C). Addition- 

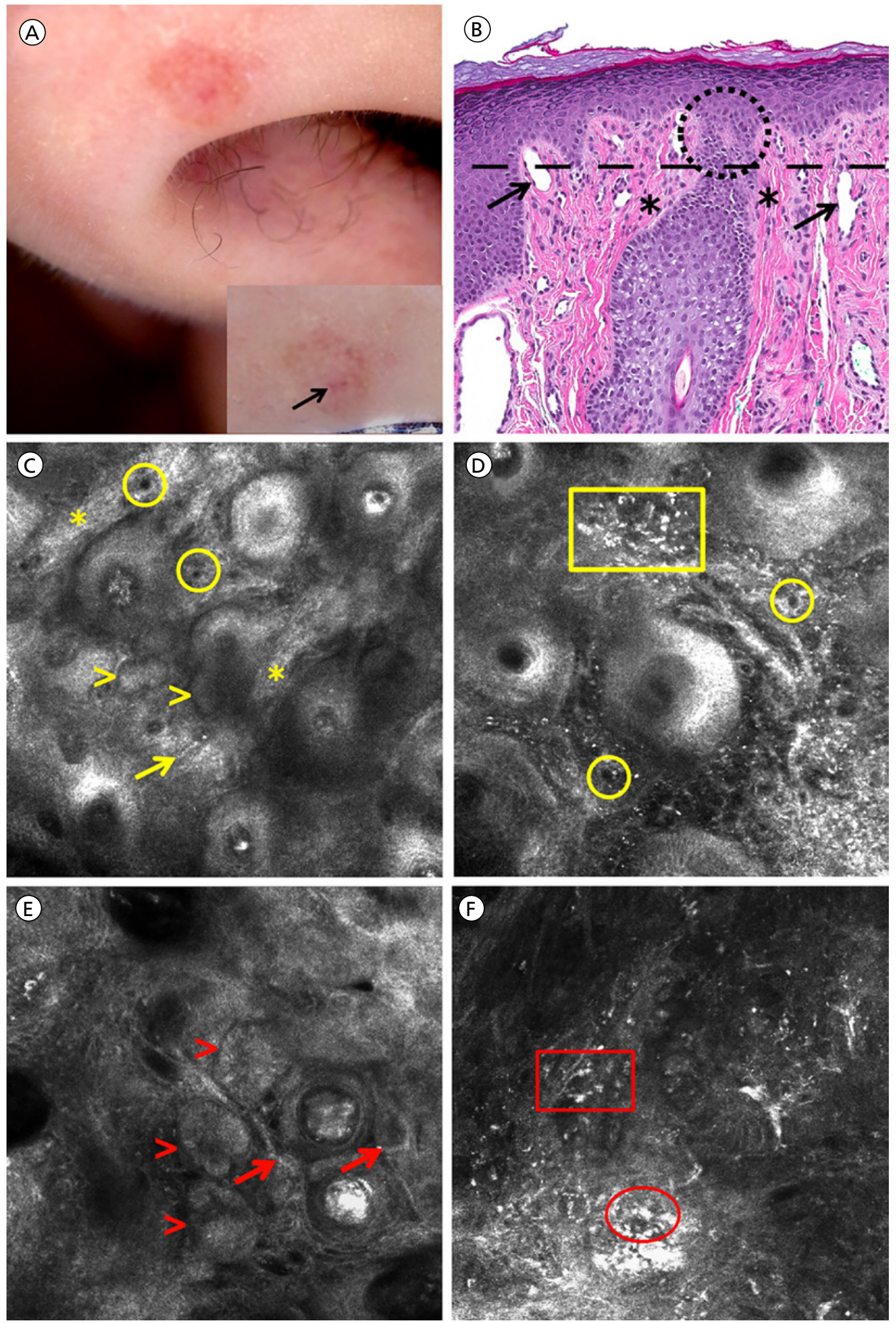

Figure 1. Clinical image of an irritated angiofibroma located on the nose (panel A) showing a superficial erosion and a whitish-reddish background on dermoscopy (arrow, inset). Corresponding hematoxylin and eosin stained histology (panel B; 20X) of angiofibroma showing dilated vessels (arrows), and abundant thick collagen bundles surrounding hair follicles (asterisks) and inflammatory cells (histiocytes and lymphocytes) in the stroma. The area encircled in panel B shows the superficial portion of external root sheath of hair follicle surrounded by thickened collagen (asterisks), which could have been the source of BCC-like nodular structures. RCM images of angiofibroma (panels C and $\mathrm{D} ; \sim 0.75 \mathrm{~mm} \times 0.75 \mathrm{~mm}$ ) taken at dermoepidermal junction (corresponding to the level of black dashed line on panel b) shows BCC-like nodular structures with clefting but no palisading (yellow arrowheads, panel C), thick collagen bundles surrounding hair follicles (asterisks, panel C), horizontal linear vessels (arrow, panel C), numerous vertical round vessels (circles, panels C and D), and numerous small bright cells and angulated cells corresponding to lymphocytes and histiocytes, respectively (yellow rectangle, panel D). Conversely, RCM images of basal cell carcinoma (panels E and F; $\sim 0.75 \mathrm{~mm}$ x $0.75 \mathrm{~mm}$; taken from a separate case) show tumor nodules with clefting and palisading (red arrowheads, panel E), horizontal canalicular vessels (red arrows, panel E), and an inflammatory stroma with numerous small bright cells (red rectangle, panel F) and plump bright cells (red ellipse, panel F). [Copyright: @2017 Millán-Cayetano et al.] 
TABLE 1. Reflectance confocal microscopy features observed in angiofibromas, comparing to those observed in BCC and histopathological correlation.

\begin{tabular}{|c|c|c|c|c|c|}
\hline & \multicolumn{2}{|c|}{ Angiofibroma } & \multicolumn{2}{|c|}{ Basal cell carcinoma } \\
\hline & & $\begin{array}{l}\text { Reflectance confocal } \\
\text { microscopy }\end{array}$ & Histopathology & $\begin{array}{l}\text { Reflectance confocal } \\
\text { microscopy }\end{array}$ & Histopathology \\
\hline \multicolumn{2}{|l|}{ Epidermis } & $\begin{array}{l}\text { Normal epidermis } \\
\text { with regular } \\
\text { honeycomb } \\
\text { pattern }\end{array}$ & - Normal epidermis & $\begin{array}{l}\text { - Epidermal } \\
\text { streaming } \\
\text { - Variable epidermal } \\
\text { disarray }\end{array}$ & $\begin{array}{l}\text { - Keratinocytes } \\
\text { focally elongated } \\
\text { along the same } \\
\text { axis } \\
\text { - Variable epidermal } \\
\text { pleomorphism }\end{array}$ \\
\hline \multirow{4}{*}{$\begin{array}{l}\text { DEJ and } \\
\text { superficial } \\
\text { dermis }\end{array}$} & Aggregates & $\begin{array}{l}\text { - Nodules with } \\
\text { increased } \\
\text { cellular density } \\
\text { and occasional } \\
\text { clefting (BCClike } \\
\text { structures) }\end{array}$ & $\begin{array}{l}\text { - Epidermal } \\
\text { invagination in the } \\
\text { papillary dermis or } \\
\text { superficial portion } \\
\text { of external root } \\
\text { sheath of hair } \\
\text { follicle }\end{array}$ & $\begin{array}{l}\text { - Tumor islands } \\
\text { - Cordlike structures } \\
\text { with palisading } \\
\text { - Clefting } \\
\text { - Dark silhouettes }\end{array}$ & $\begin{array}{l}\text { - Tumor nodules } \\
\text { comprised } \\
\text { of atypical } \\
\text { basaloid cells } \\
\text { with peripheral } \\
\text { palisading } \\
\text { - Cords of atypical } \\
\text { basaloid cells } \\
\text { - Peritumoral } \\
\text { mucin/clefting } \\
\text { - Aggregates of } \\
\text { tumor cells }\end{array}$ \\
\hline & Vascularization & $\begin{array}{l}\text { Small round } \\
\text { to linear and } \\
\text { canalicular vessels }\end{array}$ & $\begin{array}{l}\text { - Increased } \\
\text { vascularization } \\
\text { with variablysized } \\
\text { dilated blood } \\
\text { vessels }\end{array}$ & $\begin{array}{l}\text { - Horizontal } \\
\text { “enface” } \\
\text { canalicular vessels } \\
\text { with leukocyte } \\
\text { rolling/trafficking }\end{array}$ & $\begin{array}{l}\text { Prominent, dilated } \\
\text { and enlarged } \\
\text { blood vessels }\end{array}$ \\
\hline & Collagen & $\begin{array}{l}\text { Thickened } \\
\text { collagen bundles } \\
\text { surrounding } \\
\text { hair follicles and } \\
\text { BCClike structures }\end{array}$ & $\begin{array}{l}\text { - Thickened } \\
\text { collagen bundles } \\
\text { arranged around } \\
\text { hair follicles }\end{array}$ & $\begin{array}{l}\text { - Gossamer like } \\
\text { stroma wrapping } \\
\text { around tumor } \\
\text { islands }\end{array}$ & $\begin{array}{l}\text { Myxoid stroma } \\
\text { wrapping around } \\
\text { tumor nodules }\end{array}$ \\
\hline & Stroma & $\begin{array}{l}\text { - Small bright round } \\
\text { cells }\end{array}$ & - Lymphocytes & $\begin{array}{l}\text { - Numerous large } \\
\text { plump cells } \\
\text { - Dendritic cells } \\
\text { - Small bright } \\
\text { round cells }\end{array}$ & $\begin{array}{l}\text { - Melanophages } \\
\text { - Langerhans cells } \\
\text { - Melanocytes } \\
\text { - Lymphocytes }\end{array}$ \\
\hline
\end{tabular}

Abbreviations: DEJ, dermal-epidermal junction; BCC, basal cell carcinoma

ally, numerous small round (vertical) to linear and canalicular (horizontal) dilated blood vessels were seen (Figure 1C and D), as well as small bright round cells (inflammatory cells) and angulated bright cells (Figure 1D). Large plump cells (melanophages) and palisading were not identified. These findings were correlated with histopathology (Table 1).

\section{Conclusions}

Facial angiofibromas can sometimes mimic melanocytic nevi or basal cell carcinomas (BCC) under clinical and dermoscopic evaluation [2]. Reflectance confocal microscopy is useful in diagnosing melanocytic and non-melanocytic facial lesions $[3,4]$ and can be helpful in diagnosing facial angiofi- bromas that are diagnostically challenging. Favia et al have previously described the ex vivo confocal findings of a gingival angiofibroma in a patient with tuberous sclerosis [5]. They reported the presence of variably sized vessels with dilated lumina and collagen fibers with random orientation [5].

In our cases, we found structures mimicking BCC due to increased cellular density and clefting. However, unlike BCC, peripheral palisading (Figure 1E) was absent. Using vertical stacks (going from the dermis to the epidermis) we identified continuation between some BCC-like structures and hair follicles. Further, the stroma of angiofibromas lacked typical BCC features such as gossamer collagen, numerous horizontal vessels with leukocyte trafficking, and melanophages (Figure $1 \mathrm{~F})$. 
Histologically, angiofibromas are dermal proliferations containing dilated vessels, fibrosis surrounding hair follicles, stellate fibrocytes and distorted hair follicles (Figure 1B) [6,7]. We speculate that the BCC-like structures on RCM represent the base of a rete ridge, a portion of a hair follicle or another adnexal structure that due to the intense perifollicular collagen proliferation could show clefting. We also identified angulated large bright cells, which appeared smaller than melanophages and could correspond to stellate/ spindled fibrocytes [7]. The density of inflammatory cells (bright small round cells) could have been a result of irritation. A comparison between the RCM and histologic features present in our angiofibroma cases and the BCC features are summarized in Table 1.

\section{References}

1. Marino ML, Rogers T, Sierra Gil H, Rajadhyaksha M, Cordova MA, Marghoob AA. Improving lesion localization when imaging with handheld reflectance confocal microscope. Skin Res Technol. 2016;22:519-520.

2. de Cambourg G, Cribier B. [Fibrous papules of the face: a retrospective anatomoclinical study of 283 cases]. Ann Dermatol Venereol. 2013;140(12):763-770.

3. Longo C, Moscarella E, Argenziano G, et al. Reflectance confocal microscopy in the diagnosis of solitary pink skin tumours: review of diagnostic clues. Br J Dermatol. 2015;173(1):31-41.

4. Fraga-Braghiroli NA, Stephens A, Grossman D, Rabinovitz H, Castro RP, Scope A. Use of handheld reflectance confocal microscopy for in vivo diagnosis of solitary facial papules: a case series. J Eur Acad Dermatol Venereol. 2014;28(7):933-942.

5. Favia G, Tempesta A, Limongelli L, Maiorano E. Tuberous sclerosis: histological analysis with confocal laser scanning microscope of gingival angiofibromatosis. Pathologica. 2015;107(3-4):197-200.

6. Kraft S, Granter S. Fibrous and fibrohistiocytic tumors. In: Barnhill R, Crowson A, Magro C, Piepkorn M, eds. Dermatopathology. 3rd ed. New York: McGraw-Hill; 2010:766-801.

7. Misago N, Kimura T, Narisawa Y. Fibrofolliculoma/trichodiscoma and fibrous papule (perifollicular fibroma/angiofibroma): a revaluation of the histopathological and immunohistochemical features. J Cutan Pathol. 2009;36(9):943-951. 